\title{
ŹRÓDŁA NARRACYJNE DO DZIEJÓW POLONII W BOŚNI I HERCEGOWINIE W OKRESIE AUSTRO-WĘGIERSKIM
}

\author{
TOMASZ JACEK LIS
}

\begin{abstract}
Narrative sources concerning the Polish community in Bosnia and Herzegovina in the AustroHungarian period.

In my paper I make an attempt to present the current state of knowledge on the source base concerning the Polish community in Bosnia and Herzegovina in the Austro-Hungarian period. I analyze exclusively narrative sources, which I classified according to the Polish groups which appeared there (peasants, intelligentsia and soldiers). I also evaluate the usefulness of those narrative sources in my research. I briefly characterized each source naming its author, the context as well as the approximate date of the appearance of a given source, which will certainly contribute to the further research.
\end{abstract}

Autor: Tomasz Jacek Lis, Uniwersytet Mikołaja Kopernika w Toruniu, Instytut Nauk Historycznych i Archiwistyki, ul. Władysława Bojarskiego 1,87-100 Toruń, tomlis88@gmail.com

Słowa kluczowe: źródła narracyjne, pamiętniki, Polonia w Bośni i Hercegowinie

Keywords: narrative sources, memorials, Polish community in Bosnia and Herzegovina

Balcanica Posnaniensia. Acta et studia, XXII/2, Poznań 2015, Wydawnictwo Instytutu Historii UAM, pp. 75-90, ISBN 978-83-63047-88-7, ISSN 0239-4278. Polish text with a summary in English.

Żadne inne dokumenty nie są w stanie oddać ducha czasów, o których opowiadają, w takim stopniu, jak źródła narracyjne. Choć są to źródła długo lekceważone przez historyków, jako mniej wartościowe ${ }^{1}$, obecna historiografia stoi na stanowisku, że takie dokumenty, jak pamiętniki, dzienniki, czy listy, są równoprawnym źródłem, które należy traktować z niemniejszą powagą niż np. dokumenty aktowe ${ }^{2}$. Nie da się ukryć, że źródło narracyjne, dzięki swojemu subiektywizmowi jest dla historyka trudnym materiałem, nie powinno to jednak stanowić o jego wartości jako materiału badawczego $^{3}$. Wystarczy zastosować odpowiednią krytykę, zewnętrzną i wewnętrzną ${ }^{4}$, któ-

\footnotetext{
${ }^{1}$ M. Handelsman, Historyka. Zasady metodologii i poznania historycznego, Gebethner i Wolff, Warszawa 1928, s. 46.

2 Por. A. Cieński, Z dziejów pamiętników w Polsce, Uniwersytet Opolski, Opole 2002, Z. Wojtkowiak, Źródta narracyjne, pamiętnik, tekst literacki, Wydawnictwo Poznańskie, Poznań 2003.

${ }^{3}$ J. Kozakiewicz, Pamiętniki jako źródto oraz ich funkcja w procesie ksztaltowania świadomości społecznej, „Historyka”, t. 12, 1982, s. 130-131.

${ }^{4}$ Z. Wojtkowiak, O klasyfikacji i interpretacji pamiętników, „Studia Źródłoznawcze”, t. 25, 1980, s. 164 .
} 
ra pozwoli nam odpowiedzieć na najważniejsze pytania dotyczące tak autora jak i samego dokumentu 5 .

Źródła narracyjne wydają się być jednym z najbardziej odpowiednich do badań nad diasporą Polską w Bośni i Hercegowinie. Brak świadomości historycznej wśród współczesnych pokoleń dawnych polskich osadników, zwłaszcza w przypadku inteligencji polskiej w Bośni, nie ułatwia pracy historykom. Dane statystyczne nie są w stanie dać nam odpowiedzi na wiele pytań związanych z procesami akulturacji przybyszy z Galicji, ich stosunkach z lokalną ludnością, a także, roli jaką odgrywali w tym kraju. Dopiero z kart pamiętników, dzienników i listów możemy się dowiedzieć o losach tej niezwykłej emigracji, która choć odegrała w Bośni i Hercegowinie niemałą rolę, a w Polsce wydaje się zupełnie zapomniana. Warto więc poddać analizie bazę źródłową, jaką historyk zajmujący się tym zagadnieniem, posiada.

Polonia w większej liczbie, pojawiła się w Bośni i Hercegowinie w latach 1878-1914, kiedy to cesarz Franciszek Józef I, zdecydował się wpierw objąć nad tym terytorium kontrolę wojskową i administracyjną, a następnie po 30 latach włączyć je w strukturę swojej dualistycznej monarchii. Czas ten, nazywany w historiografii bośniackiej „okresem austro-węgierskim”, odznaczał się ogromną dynamiką zmian dla całego kraju. Bośnia i Hercegowina przeszła daleko idące reformy, praktycznie na każdym polu. Od kwestii społecznych, aż po gospodarkę, widać było zmiany. Jedną z najliczniejszych grup narodowych, które brały udział w modernizacji Bośni i Hercegowiny, byli przybysze z Galicji ${ }^{6}$. Liczba osób deklarujących się jako Polacy stale wzrastała. Można to zauważyć na podstawie danych statystycznych urzędników, jakie podawano do publicznej wiadomości od 1906 r. O ile w tym roku na stanowiskach urzędniczych było zatrudnionych w Bośni 482 Polaków $^{7}$, o tyle dekadę później ich liczba wzrosła do $585^{8}$ czyli o $1 / 5$.

Podobnie jest z chłopami, którzy jeszcze bardziej gromadnie przybywali do Bośni. Znamy dokładną ich liczbę w 1905 r., kiedy to oficjalnie zakończono kolonizację. Mieszkało ich tam wówczas $4233^{9}$. W 1910 r. było w Bośni i Hercegowinie ponad 11 tys. ${ }^{10}$ osób uznających się za Polaków ${ }^{11}$. Jednak pomiędzy urzędnikami a koloni-

${ }^{5}$ M. Tyrnowicz, Źródła pamiętnikarskie $w$ moich badaniach historycznych, „Pamiętnikarstwo Polskie", R 2/1 1972, s. 105-106.

6 T. J. Lis, Wkład Polaków w modernizację Bośni i Hercegowiny w okresie austro-węgierskim, „Studia Migracyjne - Przegląd Polonijny”, z 4, 2014, nr 154, s. 109-124.

7 Izvještaj o upravi Bosne i Hercegovine, Štampa za sematičke štampanje, Sarajevo, 1906, s. 27.

${ }^{8}$ Bericht über die Verwaltung von Bosnien und Hercegovina für die Jahre 1914 bis 1916, Hof- und Staatsdrückei, Wien 1917, s. 178.

${ }^{9}$ Arhiv Federacije Bosne i Hercegovine, Zajedničko Visoko Stanovništvo [dalej ABH, ZVS], 1905 , sygn. $134218 / 3$.

${ }^{10}$ J. Albin, Polacy w Jugosławii, Polonijne Centrum Kulturalno-Oświatowe Uniwersytetu Marii Curie-Skłodowskiej w Lublinie, Lublin 1983, s. 40.

11 Dużą trudność stanowi precyzyjne określenie przynależności narodowej chłopów galicyjskich, gdyż wielu z nich uważało się za ,tutejszych”. M. Łuczewski, Odwieczny naród, Wydawnictwo UMK, Toruń 2012, s. 281-282. 
stami pochodzenia chłopskiego niemal nie istniało poczucie wspólnoty. O urzędnikach galicyjskich pisał Franciszek Bujak:

\begin{abstract}
Niestety u inteligencji polskiej w Galicji do ostatnich czasów brakowało szerszego poczucia obowiązków obywatelskich i ochoty do pracy społecznej [...] wśród innych warstw społecznych, przeważał wprost antyspołeczny nastrój w umysłach galicyjskiej inteligencji ${ }^{12}$.
\end{abstract}

Niepochlebną opinię o stosunku inteligencji do chłopów potwierdzają inne źródła. Niechęć do uboższych współziomków była jednym z głównych oskarżeń, jakie czasami padały ze strony oburzonych galicyjskich dziennikarzy ${ }^{13}$. Podobna sytuacja istniała zapewne i na terenie Bośni.

Tadeusz Lubaczewski wspomina w swojej pracy poświęconej Polonii w Bośni, że oprócz inteligencji i chłopów zamieszkiwało tam również kilkaset niższych rangą pracowników administracyjnych, służby domowej, itp. ${ }^{14}$. Trudno jest jednak coś więcej powiedzieć o tej grupie, gdyż jest ona w źródłach jedynie zasygnalizowana. Większość osób pracujących na różnych stanowiskach w Bośni i Hercegowinie byli to tzw. kuferaši $i^{15}$, którzy dość często zmieniali miejsce zamieszkania, jednak wielu inżynierów (np. Robert Mączyński, Romuald Lam), nauczycieli (Kamila Kruszelnicka czy Stanisława Siwiec), a także duchownych (ks. Jan Wójcik) spędziło w Bośni i Hercegowinie większość swojego życia.

Oprócz polskiego pochodzenia kolonistów i pracowników administracji państwowej przebywali w Bośni i Hercegowinie żołnierze zmobilizowani w Galicji, którzy pełnili obowiązki w ramach stacjonującego tu kontyngentu wojskowego. Dla żołnierzy Austro-Węgier Bałkany były „,poligonem doświadczalnym”, na którym najczęściej zdobywali pierwsze żołnierskie szlify. Jest wielce prawdopodobne, że duża część żołnierzy w Wojsku Polskim z okresu II RP, jeśli wywodziła się z Galicji, swoje bojowe doświadczenie zdobywała właśnie na Bałkanach ${ }^{16}$.

Zaprezentowany powyżej podział społeczny posłuży jako klucz do systematyzacji źródeł narracyjnych dotyczących Polonii w Bośni i Hercegowinie w okresie austro-węgierskim. Należy również wprowadzić podział samego materiału. Czymś zupełnie innym są listy i wspomnienia pisane przez daną osobę, dotyczące jego indywidualnych odczuć względem siebie, jak i środowiska, a zupełnie czymś innym źródła narracyjne, które wyszły spod pióra osoby pełniącej rolę obserwatora. Zupełnie

12 F. Bujak, Galicya, Księgarnia Altenberga, Kraków 1908, s. 185.

13 W. Pec, Polskie osadnictwo w Bośni, „Przewodnik oświatowy”, 1910, nr 1, s. 402.

14 T. Lubaczewski, Osadnictwo Polskie w Bośni, Drukarnia pisma Polityka, Warszawa 1922, s. $8-10$.

15 Było to pogardliwe określenie tyczące się przybysza z innych stron monarchii, który pracował w austrowęgierskiej administracji lokalnej i często zmieniał swoje miejsce pobytu. I. Hadžibegović, Bosanskohercegovački gradovi na razmeđu 19 i 20 stoljeća, Bosanski kulturni centar, Sarajevo 2004, S. 52.

16 M. Baczkowski, Żotnierze narodowości polskiej w podboju i okupacji Bośni $i$ Hercegowiny przez Austro-Wegry (1878-1914), „Zeszyty Naukowe Uniwersytetu Jagiellońskiego, Prace Historyczne”, z. 127, 2000, s. 107-119. 
inną wartość źródłową będą miały listy Jana Karpiny, kolonisty polskiego, w których ten opisuje problemy swoje i swojej grupy, a zupełnie inną wzmianka dotycząca chłopów we wspomnieniach Jana Magiery z jego podróży na południe Europy. Dlatego, pisząc o źródłach narracyjnych należy wyraźnie rozróżnić, które z nich wyszły bezpośrednio spod pióra osoby będącej członkiem pewnej społeczności, a które tylko opisują rzeczywistość widzianą z zewnątrz.

\section{ŹRÓDŁA CHŁOPSKIE}

Narracyjne źródła chłopskie, dla wieku XIX i pierwszej połowy XX, są dla historyka bardzo rzadko spotykanym materiałem źródłowym. Ma to związek z charakterystyczną cechą polskiego chłopstwa, nie tylko tego na wychodźstwie, ale również pozostałego na rodzinnej ziemi - analfabetyzmem. Jak obliczył na początku XX wieku Antoni Lange zajmujący się problemem analfabetyzmu w Galicji, skąd wywodziła się większość polskich kolonistów w Bośni, na ponad 7 mln. obywateli, niepiśmiennych było ponad $3 \mathrm{mln}^{17}$. Stąd nie dziwi, że źródła narracyjne wytworzone przez samych chłopów są tak nieliczne. Nie tylko analfabetyzm miał wpływ na znikomą ilość źródeł opisowych, jakie ma dzisiaj do dyspozycji historyk. Nie bez znaczenia była również sama świadomość chłopów, którzy nie przywiązywali zbyt wielkiej wagi do spuścizny piśmienniczej po przodkach. Nie tworzyli więc oni, jak to miało miejsce wśród przedstawicieli warstw lepiej wykształconych i bogatszych, archiwów domowych, gdzie przechowywano korespondencję. Ponadto tryb życia chłopów, będących w nienajlepszej sytuacji finansowej powodował, że z reguły, nawet jeśli potrafili pisać, nie mieli oni najzwyczajniej czasu na spisywanie swoich wspomnień czy przemyśleń.

Nie inaczej było z chłopami emigrującymi do Bośni i Hercegowiny. Co prawda, dysponujemy, znajdującymi się w rękopisie wspomnieniami niektórych chłopów (Adam Urban i Jan Kumosz), które cytuje Tadeusz Jurkiewicz w swojej pracy, ale zostały one spisane dopiero po latach ${ }^{18}$. Są to jedyne znane wspomnienia, pochodzące od osób, które pamiętały początki emigracji jeszcze z okresu austro-węgierskiego. Więcej tego typu źródeł nie udało się dotychczas odnaleźć.

Zdecydowanie więcej uwagi należy poświęcić innemu typowi źródeł - korespondencji. Przed laty Stanisław Kościałkowski postulował wyodrębnienie materiałów epistolarnych, jako zupełnie nowego rodzaju źródła ${ }^{19}$. Pogląd ten jednak nie znalazł

17 A. Lange, Analfabetyzm i walka z ciemnota w Królestwie Polskim, Nakładem Jana Fiszera, Warszawa 1906, s. 12.

18 T. Jurkowski, Osiedlenie się Polaków z Jugosławii na terenie powiatu bolesławieckiego w latach 1946-1947, praca magisterska pisana pod kierunkiem dr hab. Leszka Winowieckiego w Wyższej Szkole Pedagogicznej w Opolu, Opole 1970, s. 45.

${ }^{19}$ S. Kościałkowski, Historyka - wstęp do studiów historycznych, Polski uniwersytet na Obczyźnie, Londyn 1954, s. 54. 
szerszego grona zwolenników, dlatego wciąż listy klasyfikowane są jako pewien rodzaj źródeł narracyjnych. Korespondencja posiada tę przewagę nad wspomnieniami (o ile nie są to dzienniki), że jest pisana „na gorąco”, przez co wiarygodność przekazu jest większa, niż w przypadku dokumentów memuarystycznych.

Niestety, do historii kolonizacji chłopskiej w Bośni i Hercegowinie również nie posiadamy zbyt wielu źródeł epistolarnych. Cenzura austro-węgierska nie dostarczyła nam takiej spuścizny jak rosyjska, dzięki której zachowały się liczne listy emigrantów z obydwu Ameryk ${ }^{20}$. Trzeba więc ograniczyć się wyłącznie do szczątkowej korespondencji, jaka pozostała w zbiorach potomków dawnych kolonistów w Bośni, którzy przybyli po II wojnie światowej na Dolny Śląsk. Przykład takiej korespondencji z okresu austro-węgierskiego znajdziemy m.in. w aneksie do książki Katarzyny Pielech $^{21}$. Jak można domniemać, zachowała się gdzieś jeszcze tego typu korespondencja, która znajduje się jednak w rękach prywatnych i jest niedostępna dla historyków.

Oprócz korespondencji rodzinnej, należy również wspomnieć o korespondencji z instytucjami rządowymi. Tego typu materiał znajduje się w Archiwum Federacji Bośni i Hercegowiny. Z innych źródeł wynika zaś, że chłopi kierowali swoje prośby również do przedstawicieli władz Galicji. Charakterystycznym elementem tych listów jest zwracanie uwagi na problemy, z jakimi spotykali się koloniści, wszechobecną nędzę, brak pomocy ze strony władz, ciężkie warunki, itd. ${ }^{22}$. W podobnym tonie utrzymana jest korespondencja z władzami kościelnymi. W liście mieszkańców Grabaśnicy skierowanym do arcybiskupa Józefa Bilczewskiego znajduje się prośba o objęcie ich opieką duszpasterską przez polskiego duchownego ${ }^{23}$. Najwięcej takich listów znajdujemy w doskonale zachowanej korespondencji o. Marcina Czermińskiego - jezuity, którego możemy śmiało uznać za duszpasterza Polonii bośniackiej. Duchowny prowadził bardzo szeroką korespondencję, a wśród osób, które doń pisały, znajdowali się także chłopi. Największa liczba listów pochodzi od wójta Miljevaca Antoniego Karpiny. Jego korespondencja kierowana do o. Czermińskiego daje doskonałe świadectwo problemów, z jakimi mieszkańcy polskich wiosek w Bośni i Hercegowinie musieli się borykać na przełomie XIX i XX wieku ${ }^{24}$. Ubóstwo, brak odpowiedniej infrastruktury, a przede wszystkim konflikty z lokalnym duchowieństwem i tęsknota za rodzimym klerem, to największe bolączki, na jakie zwracano uwagę. Zderzenie przybyszów z Galicji z rodzącym się chorwackim nacjonalizmem, reprezentowanym przez miejscowych franciszkanów, spowodowało ogromną zmianę w mentalno-

\footnotetext{
${ }^{20}$ W. Kula, N. Assarodobraj-Kula, M. Kula, Listy emigrantów z Brazylii i Stanów Zjednoczonych, PWN, Warszawa 1973, s. 8-12.

${ }^{21}$ K. Pielech, Emigracja i życie Polaków w Bośni w latach 1890-1946, ProART, Bolesławiec 2008, s. 74-77.

22 ABH, ZVS, 1902, sygn. 4 46/400, s. 2-4.

${ }^{23}$ Archiwum Kurii Metropolitalnej w Krakowie, Teki Sapieżyńskie, sygn. XX/12, List mieszkańców Grabaśnicy 21.05.1912.

${ }^{24}$ Archiwum Towarzystwa Jezusowego prowincji Południowej w Krakowie, sygn. 271/III i 271/IV, Listy Antoniego Karpiny.
} 
ści kolonistów. Żadne inne źródło, poza korespondencją, nie jest w stanie uchwycić momentu, w którym chłopi z Galicji i Bukowiny stawali Polakami. Listy chłopskie mogą i stanowią jedno z najważniejszych źródeł do zbadania ewolucji tożsamości, jaką przeszli chłopi na emigracji ${ }^{25}$.

Nieco miejsca należy również poświęcić na korespondencję publikowaną w różnych gazetach. Prawdziwą „kopalnią” tego typu tekstów, są łamy „Missyi Katolickich”, gdzie obok misjonarzy, od czasu do czasu oddawano kilka linijek dla kolonistów ${ }^{26}$. Także inne czasopisma z Galicji chętnie sięgały po chłopską korespondencję. Należy jednak pamiętać, że listy publikowane w prasie były często poddawane cenzurze. Ponadto, jeśli ktoś kierował list do redakcji, miał świadomość, że jego pismo zostanie opublikowane, przez co źródło traci nieco na swojej wiarygodności w porównaniu do korespondencji prywatnej.

\section{ŹRÓDŁA OPISUJĄCE CHŁOPSKICH KOLONISTÓW W BOŚNI}

Jak wynika z zaprezentowanego materiału, źródeł o charakterze narracyjnym wytworzonym przez chłopów jest bardzo mało. Ma na to wpływ kilka czynników, które powyżej omówiłem. Jak więc ma sobie radzić historyk, chcący zbadać „codzienność" chłopów na emigracji, jeśli nie posiada większej liczby ich listów, ani tym bardziej pamiętników? Jest to problem uniwersalny, który dotyka wszystkich badaczy, zajmujących się emigracjami chłopskimi, bez względu na to, czy chce się przyjrzeć bliżej społeczności emigrantów w Brazylii, Kanadzie, USA, czy też Bośni i Hercegowinie.

By zaradzić temu problemowi, należy sięgnąć do innych źródeł narracyjnych, w których opisani zostali chłopscy koloniści i ich problemy. Takie źródła wytworzyli ludzie, mający bezpośrednią styczność ze społecznością chłopską znajdującą się na emigracji, czyli przedstawiciele lokalnych władz oraz urzędnicy polskiego pochodzenia, którzy mieli za zadanie objąć chłopów opieką. W tej ostatniej grupie w szczególności wyróżniają się duchowni.

Historiografia polska dotychczas nie doceniła roli źródeł kościelnych w badaniach nad wychodźstwem. A są to materiały o znaczeniu trudnym do przecenienia. Polski kler na obczyźnie pełnił rolę nie tylko duchowną, ale również, a może nawet przede wszystkim, świecką, konsolidując całą społeczność. Księża i zakonnice angażowali się w życie parafii, często stając się głównymi animatorami działań wspólnoty. O ile urzędnik, przebywał wśród kolonistów krótki czas, po czym spisywał raport i wracał do siebie, o tyle duchowni spędzali ze swoimi parafianami czasem kilka lat. Doskonale znali ich problemy i potrzeby. Nie dziwi więc, że cieszyli się powszech-

${ }^{25}$ T. J. Lis, Polskie osadnictwo i duchowieństwo w Bośni i Hercegowinie od 1894 do 1920 roku, Wydawnictwo „Maria”, Toruń 2014, s. 129-131.

${ }^{26}$ Zob. A. Karpina, Z kolonii polskiej w Miljevacu, „Missye Katolickie”, R 32, 1913, s. 86. 
nym autorytetem i choć bywały od tego odstępstwa, to były to rzadkie wypadki ${ }^{27}$. Duchowni spoglądali jednak z innej perspektywy, niż perspektywa zwykłego chłopa, stąd ich relacje są nie tylko pełniejsze, ale również bardziej syntetyczne, skupiają się na problemach całej wspólnoty, a nie tylko poszczególnych osób.

Ponadto kler korespondował najczęściej nie tylko ze swoją rodziną, ale przede wszystkim ze swoimi przełożonymi lub współbraćmi. Dlatego też, większość źródeł epistolarnych, pisanych przez duchownych, zachowała się w kościelnych archiwach, gdyż tak nadawca, jak i odbiorca mieli nie tylko prawo, ale również obowiązek do archiwizacji korespondencji, która była własnością całej wspólnoty.

Do najważniejszych źródeł epistolarnych, dotyczących kolonizacji chłopskiej, z pewnością należy korespondencja siostry Leonardy Odrzywolskiej z jej przełożoną matką Magdaleną Borowską ${ }^{28}$. Całość liczy sobie niespełna 300 listów, które praktycznie dzień po dniu relacjonują przebieg misji sióstr w latach 1903-1904 w wiosce Nowy Martyniec ${ }^{29}$. Nieco mniej informacji o samych chłopach, natomiast wiele na temat stosunków na linii duchowni bośniaccy - duchowni polscy, znajdziemy w korespondencji z misji o. zmartwychwstańców, którzy przebywali w Bośni i Hercegowinie w latach 1912-1920

Nie wszystkie jednak misje są tak doskonale udokumentowane. Siostry Adoratorki Krwi Chrystusa, które wraz z chłopami w 1946 r. powróciły do Polski, posiadają w swoich zbiorach jedynie część korespondencji, jaką s. Ludwina Sikora otrzymała od swojego spowiednika o. Stanisława Chochlińskiego, krakowskiego redemptorysty $^{31}$.

Podobnie jak w przypadku chłopów i ich korespondencji drukowanej w prasie, tak i listy duchownych pojawiające się najczęściej w „Missyach Katolickich”, należy traktować z dużo większą rezerwą, niż zalegające w teczkach archiwalnych oryginalne listy.

Wspominając o źródłach narracyjnych, jakie pozostawili po sobie duchowni, nie sposób nie wspomnieć o memuarystyce. Pamiętniki (w przypadku duchownych nie zachował się żaden dziennik z ich pracy w Bośni) były spisywane z perspektywy czasu, tak w przypadku opublikowanych wspomnień o. Marcina Czermińskiego ${ }^{32}$, jak i pozostających wciąż w rękopisie wspomnień s. Leonardy Odrzywolskiej33. Analizą wspomnień krakowskiego jezuity zajmowano się już wielokrotnie, w związku z czym pomi-

27 T. J. Lis, Osadnictwo, s. 231-232.

${ }^{28}$ Zob. T J. Lis, Źródła epistolarne do dziejów misji sióstr felicjanek w Bośni i Hercegowinie w latach 1903-1904, „Perspectiva”, nr 1, R 14, (2015), s. 201-214.

${ }^{29}$ Ibidem, s. 203.

${ }^{30}$ Archivio Congregazione della Risurrezione Roma. Korespondencja poszczególnych misjonarzy.

${ }^{31}$ Archiwum Domu Prowincjalnego we Wrocławiu (dalej APAdWr), korespondencja o. Chochlińskiego do s. Ludwiny Sikory, [brak sygnatury].

32 Por. Czermiński M., Kolonie Polskie w Bośni, Drukarnia „Czasu”, Kraków 1903; Idem, Wspomnienia z misji. Nad Bosforem w Bośni i na Krecie, Drukarnia „Czasu”, Kraków 1901; Idem, Z podróży po Bośni i Hercegowinie, Drukarnia „Czasu”, Kraków 1899.

${ }^{33}$ Archiwum Generalne Zgromadzenia Sióstr Felicjanek w Rzymie (ASGF), sygn. 2236/904, Pamiętnik Leonardy Odrzywolskiej. 
nę ten wątek ograniczając się jedynie do podania odpowiedniej literatury ${ }^{34}$. Natomiast wspomnienia s. Leonardy, stanowią doskonałe dopełnienie listów, które po sobie pozostawiła. Pamiętnik, spisany po kilku latach, pozwala lepiej zrozumieć samą autorkę, pobudki jakie nią kierowały w czasie misji, jak również konsekwencje jej działań.

Kolejnym pamiętnikiem, który wspomina o polskich chłopach są wspomnienia bazylianina Józefa Gorodskiego ${ }^{35}$, Rusina wysłanego do Bośni i Hercegowiny, by dopilnował działań podjętych przez arcybiskupa Andrzeja Szeptyckiego ${ }^{36}$. Źródło to, jest o tyle istotne, że pokazuje problem wzajemnych stosunków polsko-rusińskich z zupełnie innej strony, niż miało to miejsce w materiałach tworzonych przez Polaków. W relacji Gorodskiego rzymskokatoliccy chłopi, motywowani nienawiścią, starali się zniszczyć swoich grekokatolickich sąsiadów. Przedstawia on polskich kolonistów w wyjątkowo niekorzystnym świetle, co stanowi kontrast dla źródeł tworzonych przez polskich duchownych.

Zupełnie inny rodzaj źródeł, które należy omówić tak w odniesieniu do chłopów, jak i inteligencji, stanowią pamiętniki podróżnicze, jakie pozostawili po sobie amatorzy zagranicznych wojaży. Niesieni chęcią poznania „dzikiej Europy”, jak nazywano Półwysep Bałkański, podróżnicy z różnych zaborów trafiali do Bośni i Hercegowiny, gdzie, ku własnemu zaskoczeniu trafiali na swoich rodaków. Nie sposób jest wymienić wszystkich, dłuższych lub krótszych relacji z bałkańskich podróży, gdyż ówczesna prasa często przedrukowywała dwu-trzy odcinkowe artykuły o tej tematyce. Dlatego ograniczę się wyłącznie do najważniejszych tytułów wspomnień i zawartego w nich polonijnego kontekstu.

Najwięcej informacji o chłopach spotykamy u krakowskiego slawisty Jana Magiery, który dwukrotnie opisywał w swoich książkach podróż do Bośni i Hercegowiny, a także spotkania z tamtejszymi Polakami ${ }^{37}$. To on jako pierwszy zauważył i opisał różnice majątkowe, jakie występowały wśród chłopstwa ${ }^{38}$. O swojej roli w niesieniu pomocy kolonistom pisał również zarządca Bośni i Hercegowiny z lat 1912-1915 Leon Biliński, dzięki któremu wioski zyskały pomoc materialną i duchową poprzez organizację misji duchownych z Galicjii ${ }^{39}$. Bardzo krytycznie o stosunkach między warstwami wykształconymi a chłopstwem polskim w Bośni i Hercegowinie, pisał na łamach „Nowej Reformy” inny slawista - Roman Zawiliński ${ }^{40}$.

Co ciekawe, mimo że chłopi byli zdecydowanie liczniejsi niż inteligencja, to podróżnicy częściej wspominają o tej drugiej grupie. Jest to zapewne związane z bardzo

34 F. Kwaśniak, Starania Polskiego duchowieństwa o poprawę życia duchowego Polaków w Bośni, (cz. I) „Perspectiva”, t. 15, 2009, nr 2 ss. 284-301: D. J. Gregorczyk, Misje ks. Marcina Czermińskiego SJ do Polonii bośniackiej latach 1898-1909, „Studia Bobolanum”, 2007, nr 1, ss. 47-64.

35 Й. Гродський, Положенє русинів в Боснї, Свросвіт, Львів 2003.

36 J. Magiera, Sprawa szkolna Polaków w Bośni, ,Świat Słowiański”, R. 8, 1912, s. 271-273.

${ }^{37}$ Idem, Ludność Polska w Bośni, Księgarnia literacka Karola Kwaśniewskiego, Kraków 1912: Idem, Na Yugu słowiańskim, Księgarnia literacka Karola Kwaśniewskiego, Kraków 1911.

38 Opisał dużą grupę osób, które nie posiadały swoich parceli i mieszkały „na komorze”, pracując za miejsce do spania.

${ }^{39}$ L. Biliński, Wspomnienia i dokumenty, t. 1-2, F. Hoesick, Warszawa 1924-1925, s. 227-228.

${ }^{40}$ R. Zawiliński, Z włóczęgi po słowiańszczyźnie, „Nowa Reforma” z dn. 25.12.1904, nr 296, s. 8. 
trudną dostępnością polskich wiosek, które założone w środku puszczy nie posiadały odpowiedniej infrastruktury. Dopiero w dwudziestoleciu międzywojennym szerzej tematem polskich osadników w Bośni zajęła się Maria Dąbrowska ${ }^{41}$.

\section{ŹRÓDŁA NARRACYJNE DO DZIEJÓW INTELIGENCJI POLSKIEJ W BOŚNI I HERCEGOWINIE}

Dość często we wspomnieniach podróżniczych pojawiają się Polacy pracujący na różnych stanowiskach w służbie Austro-Węgier. Wielokrotnie wymieniany o. Marcin Czermiński miał z nimi, podobnie jak z chłopami, bardzo dobry kontakt, między innymi w 1909 r. poprowadził on rekolekcje dla Polaków w Sarajewie ${ }^{42}$. Także Adam Stefan Sapieha, późniejszy kardynał, podczas swojej wycieczki w 1896 r. opisał spotkanie z Polakami w stolicy Bośni ${ }^{43}$, co jednak nie dziwi, jego brat Paweł pracował tam przez kilka lat jako urzędnik ${ }^{44}$. O roli polskich lekarzy w rozwoju bośniacko-hercegowińskiej służby zdrowia pisał Stanisław Bełza, wtórowała mu przy tym Maria Jakubowska z Seredyńskich, która to szczególnie podkreślała, jak istotne zadania mają na tym terenie kobiety lekarki ${ }^{45}$.

W przypadku inteligencji, źródła narracyjne pojawiają się zdecydowanie częściej, niż w przypadku chłopstwa. Ilość wytworzonego materiału, a także stan jego zachowania miały na to bezpośredni wpływ. Mimo to kwerenda nastręcza ogromnych problemów badaczowi. Ma to związek przede wszystkim z faktem, że duża część osób pracujących w administracji austro-węgierskiej w Bośni i Hercegowinie po I wojnie światowej powróciła do Polski. Ze względu na doświadczenie w pracy biurowej, urzędnicy z Galicji byli w II RP cenionymi fachowcami, chętnie zatrudnianymi w całym kraju. Ze względu na to, źródła dotyczące urzędników są rozproszone po całej Polsce. Ślady osób pracujących w Bośni i Hercegowinie, które powróciły do Polski po I wojnie światowej możemy znaleźć od Gdańska aż po Kraków.

Powoduje to wiele problemów, gdyż poszukiwania materiału źródłowego wymagają bardzo szczegółowej kwerendy, której efekt może być i tak niesatysfakcjonujący. Źródła narracyjne wytworzone przez urzędników, stanowią częściej pamiątkę rodzinną niż materiał, który ktoś zechciałby zdeponować w archiwum. Tak jest m.in. w przypadku korespondencji Teodory Krajewskiej, o której wspomina edytorka jej

\footnotetext{
${ }^{41}$ B. Vranješ-Šoljan, Maria Szumska Dabrowska o poljskim doseljenicima u Bosni 1935. Godine,"Časopis za suvremenu povijest", R. 38, 2006, nr 3, ss. 955-965.

${ }^{42}$ F. Kwaśniak, Starania Polskiego duchowieństwa o poprawę życia duchowego Polaków w Bośni, (cz. I) „Perspectiva”, t. 15, 2009, nr 2 s. 292.

${ }^{43}$ Muzeum Narodowe w Krakowie (dalej: MNK), sygn. VIII-Rkps-a-1182, List A.S. Sapiehy, 30.10.1896.

${ }^{44}$ P. Żurek, Polska i Polacy w życiu Josipa Jurija Strossmayera, Wydawnictwo Akademii Techniczno-Humanistycznej, Bielsko Biała 2005, s. 88.

${ }^{45}$ M. Jakubowska z Seredyńskich, Z pobytu w Bośni, Wydawnictwo „Katolik”, Bytom, 1891, s. $70-78$.
} 
pamiętnika, Bogusława Czajecka ${ }^{46}$. Znajdowała się ona w rękach prywatnych, dzisiaj zaś jej los jest nieznany.

Bardzo interesująca jest korespondencja Franciszka Jakubowskiego, kierownika obwodu Jajce, w którym znajdowały się również kolonie polskie. Napisanych przez niego w latach 1905-1913, 10 listów do ks. Marcina Czermińskiego daje bardzo interesujący obraz problemów społecznych i politycznych w Bośni i Hercegowinie. Korespondencja ma charakter prywatny i znajduje się w niej wiele intrygujących przemyśleń $m$. in. na temat katolicyzowania bośniackich wsi przez osadników z Galicji ${ }^{47}$. Możemy się z nich również sporo dowiedzieć na temat konfliktu w łonie tamtejszego kościoła katolickiego, jaki zaistniał między franciszkanami a arcybiskupem Josipem Stadlerem ${ }^{48}$.

W dziale rękopisów Biblioteki Narodowej w Zagrzebiu znajduje się z kolei korespondencja między znanym później chorwackim pisarzem i publicystą, thumaczem literatury polskiej Julijem Benešićem a Henrykiem Glückiem, którego ojciec Leopold był pierwszym dyrektorem Szpitala Koševo w Sarajewie ${ }^{49}$. Po I wojnie światowej Henryk Glück został dyrektorem kopalń na Śląsku, gdzie zmarł w latach dwudziestych. W innych przypadkach udało się odnaleźć wyłącznie pojedyncze listy urzędników pracujących w Bośni i Hercegowinie. W Bibliotece Jagiellońskiej w Krakowie zachowało się kilka listów lekarza - Naczelnego Inspektora Sanitarnego Bośni i Hercegowiny, dr. Justyna Karlińskiego, szwagra słynnego krakowskiego profesora Ludwika Birkenmajera ${ }^{50}$. Wspomnieć też należy o listach podróżnika Pawła Sapiehy ${ }^{51}$ oraz spuściźnie urodzonej w Bośni, a osiadłej później w Poznaniu Zofii Kaweckiej, znanej tłumaczki języka serbsko-chorwackiego ${ }^{52}$. Jak już zostało powiedziane, ze względu na rozproszenie materiału, praktycznie w każdej bibliotece i w każdym archiwum w Polsce mogą znajdować się jakieś tego typu źródła.

Inteligencja, w przeciwieństwie do chłopów, zdecydowanie częściej sięgała po pióro, dzięki czemu dzisiaj dysponujemy kilkoma pamiętnikami, które rzucają wiele światła na historię tej grupy. Wśród najważniejszych źródeł z pewnością należy wymienić Pamiętnik Teodory Krajewskiej. Lekarka, która 34 lata spędziła w Bośni spisała swoje wspomnienia pod koniec życia ${ }^{53}$. Nie jest to jednak typowy pamiętnik, gdyż pisząc go, korzystała z kilkunastu dzienników, jakie prowadziła mieszkając w Bośni i Hercegowinie. Trudno sobie wyobrazić, jakim źródłem musiały być owe

46 T. Krajewska, Pamiętnik, PIW, Kraków 1989, s. 21.

${ }^{47}$ Archiwum Towarzystwa Jezusowego w Krakowie [dalej ATJKr], sygn. 272/III, 272/IV, 272/V, 272/VI, Korespondencja Franciszka Jakubowskiego do Marcina Czermińskiego.

48 Zob. V. Blaževič, Bosanski franjevci i nadbiskup dr. Josip Stadler, Svjetlo riječi, Sarajevo 2000.

${ }^{49}$ E. Stocki, Leopold Glück, Polski Słownik Biograficzny, z. 36, t. 8, 1959, s. 89: Nacjonalna i Sveučilišna Knjižnica u Zagrebu, Zbirka Rukopisa, Korespondencija, Julije Benešić, sygn. 492.

${ }^{50}$ Biblioteka Jagiellońska, Oddział Rękopisów [dalej BJ, Rkps], sygn. 309/08, Archiwum Birkenmajerów, Dokumenty Justyna Karlińskiego.

${ }^{51}$ P. Żurek, op. cit., s. 81.

52 Biblioteka Uniwersytecka w Poznaniu, Oddział Rękopisów, sygn. 3180-3189, Spuścizna Zofii Kaweckiej.

${ }^{53}$ T. Krajewska, op. cit., s. 20-21. 
dzienniki, które, niestety, w czasie II wojny światowej uległy zniszczeniu ${ }^{54}$. Dzisiaj dysponujemy wyłącznie kompilacją jej wspomnień, niestety, ze względu na śmierć autorki, doprowadzoną tylko do $1905 \mathrm{r}$.

Wspomnienia Krajewskiej pokazują nie tylko jej zmagania z codzienną pracą wśród ludności muzułmańskiej, ale są przede wszystkim najlepszym źródłem narracyjnym do historii Polonii w Bośni i Hercegowinie. Chociaż należy z rezerwą traktować niektóre opinie pochodzącej z Warszawy lekarki, krytyka wewnętrzna źródła pozwala ocenić, że jest to materiał rzetelnie oddający zaprezentowane fakty.

Krajewska nie była jedyną polską lekarką pracującą w Bośni i Hercegowinie. Oprócz niej pracowały tam jeszcze Jadwiga Olszewska i Bronisława CałczyńskaPrašek. Ostatnia z nich, podobnie jak Teodora, pozostawiła po sobie wspomnienia. Wydane one zostały dwukrotnie w Chorwacji w latach 1997 i $2005^{55}$. CałczyńskaPrašek, chociaż spędziła w Bośni zaledwie kilka lat, swojemu pobytowi w Sarajewie poświęciła dużo miejsca. Szczególnie cenne w jej pamiętniku są informacje na temat ewakuacji inteligencji polskiej z Bośni w latach 1919-1920, kiedy to duża część urzędników polskiego pochodzenia zdecydowała się opuścić Bałkany, by powrócić do II Rzeczypospolitej ${ }^{56}$.

Równie interesujące, choć wciąż pozostające wyłącznie w rękopisie są wspomnienia Artura Burdy, honorowego konsula w Bośni i Hercegowinie w okresie międzywojennym, który to spisał historię swojej rodziny. Rękopis spoczywa w Archiwum Republiki Serbskiej w Banja Luce ${ }^{57}$.

Kolejnym pozostającym wciąż w rękopisie źródłem memuarystycznym są wspomnienia Jana Stanisława Mieroszewskiego, które zostały zdeponowane w Oddziale Rękopisów Biblioteki Jagiellońskiej ${ }^{58}$. Z pobieżnej lektury wspomnień wynika, że Mieroszewski miał wobec Bośni i Hercegowiny bardzo poważne plany. Jak sam twierdzi, to on jako pierwszy poddał pomysł utworzenia instytucji naukowej, mającej badać historię tej części Półwyspu Bałkańskiego. Sobie również przypisywał ideę kolonizacji Bośni i Hercegowiny, której chciał dokonać za pomocą chłopskich osadników. Niestety nie udało mu się zrealizować planów, które sobie założył, gdyż, jak to często bywało w jego przypadku, skonfliktował się ze swoimi zwierzchnikami i musiał opuścić Sarajewo. Trudno powiedzieć, w jakim stopniu realne były pomysły i założenia Mieroszewskiego. Z pewnością jego wspomnienia powinny zostać poddane głębszej analizie pod kątem ewentualnego wpływu na Beniamina Kàllaya, któremu przypisuje się pomysł i realizację projektu kolonizacji ${ }^{59}$.

\footnotetext{
54 Ibidem.

55 B. Całczyńska-Prašek, Memoare jedne liječnice, Durieux, Zagreb, 2005.

${ }^{56}$ H. Kamberović, Iseljavanje Poljaka iż Bosne i Herzegovine 1946. godine, „Časopis za sovremenu povijest", R. 30, 1998, nr 1, s. 100-101.

57 Zob. Ł. Chimiak, Z dziejów polskiej mniejszości w Bośni. Życie i działalność Wiktora i Artura Burdów, „Studia z dziejów Rosji i Europy Środkowo-Wschodniej”, 2013, nr 48, s. 57, przypis.

58 BJ, Rkps 130/58, Spuścizna Jana Stanisława Mieroszewskiego, Z pobytu w Bośni.

59 Zob. T. Kraljačić, Kallayev režim u Bosni i Hercegovini, Svjetlost, Sarajevo 1987.
} 
Bardzo interesujące są wspomnienia osób, które spędziły w Bośni i Hercegowinie dzieciństwo, lecz po zakończeniu I wojny światowej, jako młodzi ludzie, powrócili do II Rzeczpospolitej. Dysponujemy kilkoma takimi wspomnieniami. Spośród nich wybijają się niewydane pamiętniki Izabelli Dulębskiej ${ }^{60}$, która pochodziła z mieszanej rodziny węgiersko-polskiej, i po odzyskaniu przez Polskę niepodległości zamieszkała wraz z rodzicami w Bydgoszczy. Jej traumatyczne przeżycia związane z podróżą z Bośni do Polski (która przypadała na okres bitwy warszawskiej), a także bardzo emocjonalne opisy pierwszych lat spędzonych w mieście nad Brdą, stanowią doskonałą lekturę.

Ciekawe są również pamiętniki Adama Ferensa ${ }^{61}$, który po śmierci matki wyjechał do ojca, urzędnika w Bośni i Hercegowinie, gdzie mieszkał przez krótki czas. Silne przeżycia, spowodowane różnicą kultur odcisnęły piętno na psychice młodzieńca, czego dowodem są spisane po latach wspomnienia. Opis życia codziennego mieszkańców miast bośniackich, ich strojów, a także architektury, pozwalają lepiej zrozumieć, jak bardzo dużym szokiem kulturowym był dla Polaków wyjazd do Bośni i Hercegowiny.

Jedynymi wydanymi drukiem wspomnieniami osób z tzw. „drugiej generacji62" emigracji bośniackiej są fabularyzowane pamiętniki Władysława Lama, który na opis swojego szczęśliwego dzieciństwa na Bałkanach poświęcił dwie krótkie książki Światta i cienie $^{63}$, a także Miasteczko nad Neretwa ${ }^{64}$. Ze względu na fakt, że zostały one wydane przez samego autora, a także, że zdecydował się on przed śmiercią zniszczyć większość materiałów ${ }^{65}$, z których korzystał pisząc je, należy podchodzić z dużą rezerwą do treści, jakie prezentuje.

Pamiętniki spisane po latach przez osoby, których dzieciństwo i młodość upłynęła w austrowęgierskiej Bośni i Hercegowinie, stanowią doskonałe źródło nie tylko dla historyka, ale również antropologa, czy pedagoga. Powtarzający się motyw idyllicznego dzieciństwa w pięknym i słonecznym kraju powoduje, że możemy postawić tezę o pewnym schemacie związanym z oceną tego okresu.

Co do żołnierzy, poza listami, jakie znajdziemy w gazetach galicyjskich opisujących kampanie z lat $1878^{66}$ i $1882^{67}$, udało się odnaleźć zaledwie jedną relację pamiętnikarską autorstwa Jana Karola Mieroszewskiego (syna Jana Stanisława, o którym wcześniej była mowa). Jest ona bardzo interesująca, gdyż autor, jako podporucznik

60 Biblioteka Uniwersytetu Kazimierza Wielkiego w Bydgoszczy, Pracownia Pamięć Bydgoszczan i Regionu, [dalej BUKW, PPBiR] Spuścizna Haliny Stasiak, [brak sygnatury].

61 BJ, Rkps 45/68, Spuścizna Adama Ferensa, Na fali wspomnień.

62 O „drugiej generacji” zob. T. J. Lis, Bosna u mojoj krvi-Druga generacija Poljaka u Bosni i Hercegovini [w:] Poljska u Bosni, Bosna u Poljskoj, [red. T. J. Lis, M. Maleszka], Kraków-Toruń-Sarajevo 2015, s. 93-109.

63 W. Lam, Światła i Cienie, Wydawnictwo Morskie, Gdańsk 1984.

${ }^{64}$ Idem, Miasteczko nad Neretwa, Wydawnictwo Morskie, Gdańsk 1973.

65 S. Bajcer-Nowak, Helena, kobieta, która jest i której nie ma, Wydawnictwo UJ, Kraków 2013, s. 52.

66 „Czas”, 1878, nr 227.

67 „Czas”, 1882, nr 29. 
huzarów, miał dostęp do wielu informacji. Jego relacje dotyczą nie tylko kwestii wojskowych, ale również spraw związanych z samą Bośnią i Hercegowiną ${ }^{68}$. Biorąc pod uwagę, jak wielu żołnierzy z Galicji zdobywało doświadczenie bojowe na Bałkanach, należy spodziewać się, że archiwalne półki kryją jeszcze więcej tego typu materiałów.

Istnieje duże prawdopodobieństwo, że dalsza kwerenda $\mathrm{w}$ archiwach polskich i zagranicznych pozwoli odnaleźć jeszcze więcej materiału źródłowego wytworzonego przez emigrantów polskich w Bośni z różnych grup społecznych. Pamiętniki, dzienniki, czy listy mówią do nas językiem, którego nie jesteśmy w stanie odnaleźć w innych śladach z przeszłości, jakimi posługuje się historyk. Są one tak samo wartościowe, jak inne materiały źródłowe, a przez swój wyjątkowy charakter, pozwalają lepiej zrozumieć człowieka.

\section{BIBLIOGRAFIA}

\section{Literatura}

[brak autora], Bośnia i Hercegowina, „Czas”,1878, nr 227.

[brak autora], Korespondencya zagraniczna, „Czas”, 1882, nr 29.

Albin Janusz, Polacy w Jugosławii, Polonijne Centrum Kulturalno-Oświatowe Uniwersytetu Marii CurieSkłodowskiej w Lublinie, Lublin 1983.

Baczkowski Michał, Żotnierze narodowości polskiej w podboju i okupacji Bośni i Hercegowiny przez Austro-Węgry (1878-1914), „Zeszyty Naukowe Uniwersytetu Jagiellońskiego, Prace Historyczne”, 2000, z. 127, ss. 107-119.

Rőmer Eugeniusz, Rocznik Polski. Tablice statystyczne, Gebethner i Wolff, Kraków 1917.

Bajcer-Nowak Sylwia, Helena, kobieta, która jest i której nie ma i która jest, Wydawnictwo UJ, Kraków 2013.

Bericht über die Verwaltung von Bosnien und Hercegovina für die Jahre 1914 bis 1916, Hof- und Staatsdrückei, Wien 1917.

Biliński Leon, Wspomnienia i dokumenty, t. 1-2, F. Hoesick, Warszawa 1924-1925.

Blaževič Velimir, Bosanski franjevci i nadbiskup dr. Josip Stadler, Svjetlo riječi, Sarajevo 2000.

Bujak Franciszek, Galicya, Księgarnia Altenberga, Kraków 1908.

Całczyńska-Prašek Bronisława, Memoare jedne liječnice, Durieux, Zagreb 2005.

Chimiak Łukasz, Z dziejów polskiej mniejszości w Bośni. Życie i działalność Wiktora i Artura Burdów, „Studia z dziejów Rosji i Europy Środkowo-Wschodniej”, 2013, nr 48, ss. 55-74.

Cieński Andrzej, Z dziejów pamiętników w Polsce, Uniwersytet Opolski, Opole 2002.

Czermiński Marcin, Kolonie Polskie w Bośni, Drukarnia „Czasu”, Kraków 1903.

Czermiński Marcin, Wspomnienia z misji. Nad Bosforem w Bośni i na Krecie, Drukarnia „Czasu”, Kraków 1901.

Czermiński Marcin, Z podróży po Bośni i Hercegowinie, Drukarnia „Czasu”, Kraków 1899.

Gregorczyk Dariusz, Misje ks. Marcina Czermińskiego SJ do Polonii bośniackiej latach 1898-1909, „Studia Bobolanum” Nr 1, (2007), ss. 47-64.

Hadžibegović Iljas, Bosanskohercegovački gradovi na razmeđu 19 i 20 stoljeća, Bosanski kulturni centar, Sarajevo 2004.

Handelsman Marceli, Historyka. Zasady metodologii i poznania historycznego, Gebethner i Wolff, Warszawa 1928.

${ }^{68}$ BJ, Rkps 9714, K. E. Mieroszewski, Slużba moja w Bośni od 1880 do 1882. 
Izvještaj o upravi Bosne i Hercegovine, Štampa za sematičke štampanje, Sarajevo 1906.

Jakubowska z Seredyńskich Maria, Z pobytu w Bośni, Wydawnictwo „Katolik”, Bytom, 1891.

Jurkowski Tadeusz, Osiedlenie się Polaków z Jugosławii na terenie powiatu bolesławieckiego $w$ latach 1946-1947, praca magisterska pisana pod kierunkiem dr hab. Leszka Winowieckiego w Wyższej Szkole Pedagogicznej w Opolu, Opole 1970.

Kamberović Husnija, Iseljavanje Poljaka iż Bosne i Herzegovine 1946. godine, „Časopis za suvremenu povijest", 1998, R 30, nr 1, ss. 95-104.

Karpina Antoni, Z kolonii polskiej w Miljevacu, „Missye Katolickie”, R 32, (1913), ss. 86.

Kościałkowski Stanisław, Historyka - wstęp do studiów historycznych, Polski uniwersytet na Obczyźnie, Londyn 1954.

Kozakiewicz Jerzy, Pamiętniki jako źródło oraz ich funkcja w procesie ksztaltowania świadomości spotecznej, „Historyka: studia metodologiczne”, 1982, t. 12, ss. 129-136.

Krajewska Teodora, Pamiętnik, PIW, Kraków 1989.

Kraljačić Tomislav, Kallayev režim u Bosni i Hercegovini, Svjetlost, Sarajevo 1987.

Kula Witold, Assarodobraj-Kula Nina, Kula Marcin, Listy emigrantów z Brazylii i Stanów Zjednoczonych, PWN, Warszawa 1973.

Kwaśniak Franciszek, Starania Polskiego duchowieństwa o poprawę życia duchowego Polaków w Bośni. Cz. I., „Perspectiva”, 2009, t. 15, Nr 2, ss. 284-301.

Lam Władysław, Miasteczko nad Neretwa, Wydawnictwo Morskie, Gdańsk 1973.

Lam Władysław, Światta i Cienie, Wydawnictwo Morskie, Gdańsk 1984.

Lange Antoni, Analfabetyzm i walka z ciemnota w Królestwie Polskim, Nakładem Jana Fiszera, Warszawa 1906.

Lis Tomasz Jacek, Źródła epistolarne do dziejów misji sióstr felicjanek w Bośni i Hercegowinie w latach 1903-1904, „Perspectiva”, 2015, R. 14, nr 1, ss. 201-214.

Lis Tomasz Jacek, Bosna u mojoj krvi - Druga generacija Poljaka u Bosni i Hercegovini, w: Poljska u Bosni, Bosna u Poljskoj, [T. J. Lis, M. Maleszka (red.)], Kraków-Toruń-Sarajevo 2015, ss. 93-109.

Lis Tomasz Jacek, Polskie osadnictwo i duchowieństwo w Bośni i Hercegowinie od 1894 do 1920 roku, Wydawnictwo „Maria”, Toruń 2014.

Lis Tomasz Jacek, Wkład Polaków w modernizację Bośni i Hercegowiny w okresie austro-węgierskim, „Studia Migracyjne - Przegląd Polonijny”, 2014, nr 154, z 4, ss. 109-124.

Lubaczewski Tadeusz, Osadnictwo Polskie w Bośni, Drukarnia pisma Polityka, Warszawa 1922.

Łuczewski Michał, Odwieczny naród, Wydawnictwo UMK, Toruń 2012.

Magiera Jan, Ludność Polska w Bośni, Księgarnia literacka Karola Kwaśniewskiego, Kraków 1912.

Magiera Jan, Na Yugu stowiańskim, Księgarnia literacka Karola Kwaśniewskiego, Kraków 1911.

Magiera Jan, Sprawa szkolna Polaków w Bośni, „Świat Słowiański”, 1912, R. 8, ss. 271-273.

Pec Władysław, Polskie osadnictwo w Bośni, „Przewodnik oświatowy”, 1910, nr 1, s. 402.

Pielech Katarzyna, Emigracja i życie Polaków w Bośni w latach 1890-1946, ProART, Bolesławiec 2008.

Stocki Edward, Leopold Glück, Polski Słownik Biograficzny, 1959, z. 36, t. 8, s. 89.

Tyrnowicz Marian, Źródta pamiętnikarskie w moich badaniach historycznych, „Pamiętnikarstwo Polskie”, 1972, R. 2/1, ss. 105-106.

Vranješ-Šoljan Božena, Maria Szumska Dabrowska o poljskim doseljenicima u Bosni 1935. Godine,"Časopis za suvremenu povijest", 2006, R. 38, Nr 3, ss. 955-965.

Wojtkowiak Zbysław, O klasyfikacji i interpretacji pamiętników, „Studia Źródłoznawcze”, t. 25, (1980), ss. 163-177.

Wojtkowiak Zbysław, Źródła narracyjne, pamiętnik, tekst literacki, Wydawnictwo Poznańskie, Poznań 2003.

Zawiliński Roman, Z włóczęgi po stowiańszczyźnie, „Nowa Reforma” z dn. 25.12.1904, nr 296, s. 8.

Żurek Piotr, Polska i Polacy w życiu Josipa Jurija Strossmayera, Wydawnictwo Akademii Techniczno-Humanistycznej, Bielsko Biała 2005.

Гродський Йосип, Положенє русинів в Боснії, Євросвіт, Львів 2003. 


\section{Archiwalia}

Archivio Congregazione della Risurrezione Roma:

- Korespondencja poszczególnych misjonarzy.

Archiwum Domu Prowincjalnego we Wrocławiu:

- Korespondencja o. Chochlińskiego do s. Ludwiny Sikory, [brak sygnatury].

Archiwum Generalne Zgromadzenia Sióstr Felicjanek w Rzymie:

- Pamiętnik, Leonardy Odrzywolskiej sygn. 2236/904.

Archiwum Kurii Metropolitalnej w Krakowie:

- Teki Sapieżyńskie.

Archiwum Towarzystwa Jezusowego prowincji Południowej w Krakowie:

- Korespondencja M. Czerminskiego.

Arhiv Federacije Bosne i Hercegovine:

- Zajedničko Visoko Stanovništvo.

Biblioteka Uniwersytecka w Poznaniu:

- Oddział Rękopisów, Spuścizna Zofii Kaweckiej.

Biblioteka Uniwersytetu Kazimierza Wielkiego w Bydgoszczy.

- Pracownia Pamięć Bydgoszczan i Regionu.

Biblioteka Jagiellońska, Oddział Rękopisów:

- Archiwum Birkenmajerów

- K. E. Mieroszwski, Służba moja w Bośni od 1880 do 1882.

- Spuścizna Adama Ferensa.

- Spuścizna Jana Stanisława Mieroszewskiego.

Muzeum Narodowe w Krakowie:

- Listy A. S. Sapiehy.

Nacjonalna i Sveučilišna Knjižnica u Zagrebu:

- Zbirka Rukopisa, Korespondencija. 
